\title{
Sustainable guidelines for enhancing indoor thermal comfort in Coptic Churches in Egypt using passive design strategies; Case Study St. Barbarah and Virgin Mary Churches
}

\author{
KATEI YASSA ${ }^{1}$, GEHAN NAGY ${ }^{1}$ \\ ${ }^{1}$ Faculty of Engineering, The British University in Egypt, El-Sherouk City, Cairo, EGYPT
}

\begin{abstract}
Since the $20^{\text {th }}$ century, the temperature has risen, worldwide, due to climate change causing global warming. Such phenomena have resulted in thermal dissatisfaction within various buildings indoor spaces including Egyptian Coptic Orthodox churches. Heritage churches designs have always implemented passive strategies to provide indoor thermal comfort. However, modern churches design tend to use active strategies to provide indoor thermal satisfaction instead of referring to the use of passive designs. Accordingly, the main purpose of this research is to identify a set of guidelines to enhance indoor thermal comfort in modern Coptic Orthodox churches using passive design strategies. The research has adapted a mixed method approach where an in-depth literature review resulting a qualitative summary of passive techniques used in heritage Coptic churches, then followed by a comparative analysis between two Egyptian case studies; the first is a heritage church (St. Barbarah church) and the other is modern which is (Virgin Mary church) based on the deducted passive strategies from the literature. Moreover, an applicable simulation for varying the methodology, using Design Builder, where the modern church will be simulated and tested for thermal comfort before and after modifying it using the passive strategies deducted from the literature. The research's main findings were the list of passive techniques that could be used to enhance the indoor thermal comfort, while the simulation experimental results where related to a typical summer week, showing that for the average air temperature and the average solar gains, the triple glazing was the most effective in causing indoor thermal comfort. But, for the average relative humidity and average of total fresh air, insulation has shown to be most effective in providing enhanced indoor thermal comfort. To conclude, a set of guidelines has been deduced from the methods adapted in the research showing the most suitable and applicable passive design strategies that could be used inside Coptic Orthodox churches to enhance indoor thermal comfort.
\end{abstract}

Key-Words: Passive design strategies, thermal comfort, Coptic Orthodox church, climate change, Coptic architecture

Received: August 30, 2020. Revised: February 28, 2021. Accepted: March 18, 2021. Published: April 1, 2021.

\section{Introduction}

The high rise in temperature due to greenhouse gases (carbon dioxide, methane, etc.) and deforestation contributes to changes in global climate patterns since the early 20th century causing climate change also known as global warming [1], [2]. As a result, this affects mainly desert areas such as Egypt, leading to a negative effect on indoor spaces causing thermal dissatisfaction in different buildings including Coptic Orthodox churches [2].

Coptic architecture is an Egyptian heritage represented in the Coptic Orthodox church whose style and elements were formulated in Egypt due to its geography, climate and the surrounding civilizations it emerged within [3]-[6]. The Coptic church's architecture design, specifically, the use of passive design strategies has changed throughout the decades due to ancient and existing civilizations, culture and beliefs, a whole set of environmental, economic, cultural, political forces, historical architectural buildings, building material and climate, etc. [6]-[8].

\section{Problem}

Indoor thermal comfort has been an uprising challenge for architects because of global 
warming and rapid industrialization in contemporary architecture [1]. Several researches specialized their passive strategies investigation in several building types such as; mixed mode ventilated building, educational building, etc [9]-[14]. While there is a gap in thermal comfort studies related to passive strategies in church building. Moreover, it has been noticed that old architecture has used passive strategies in their design which explains the indoor thermal comfort provided [15]. But, in modern buildings passive strategies are neglected which caused indoor thermal dissatisfaction and as a solution, active strategies were used instead. Therefore, the main problem of this research is the indoor thermal dissatisfaction in modern Coptic Orthodox churches in Egypt and the neglection of passive design techniques.

Therefore, the main aim of this research is to identify a set of guidelines for implementing passive strategies in modern Coptic Orthodox Churches in Egypt to enhance indoor thermal comfort. Several secondary aims are to be achieved; to investigate key factors related to thermal comfort in churches, to investigate passive strategies that could improve thermal comfort in church design, to identify the reasons of thermal dissatisfaction in current Coptic Orthodox Church in Egypt and to analyse passive techniques used in Coptic Orthodox churches.

The research will employ a qualitative into quantitative approach. A comparative analysis is done between two local cases; a historical Coptic church (St. Barbara) and a modern church (Virgin Mary). An applicable study is also done using simulation to modify various passive design strategies in the modern Coptic Orthodox church and identify their effect on the indoor space.

\section{Literature review: Passive Strategies in Coptic Orthodox churches}

The literature review has included the various definitions of thermal comfort which concluded to be a condition of mind of satisfaction expressed with the thermal environment [16][18]. Moreover, illustrating the factors affecting thermal comfort and the different thermal comfort strategies [14], [19]-[25]. Then focusing on passive strategies in arid climate and the different types that participate in enhancing indoor thermal comfort [24], [26][28]. In addition, demonstrating the different church typologies along with an example for each type to observe the passive strategies implemented in them [4], [5], [29], [30]. Lastly, computer modelling tools were explained, focusing mainly on DesignBuilder as it was the tool used for simulation in this research.

The Literature review helped in identifying various passive design techniques that will help enhance indoor thermal comfort and be suitable in churches. These passive techniques were used to select from them the most suitable, economic, fast and applicable strategy to be modified in the modern church (Virgin Mary church).

\section{Analytical Study}

The two case studies were chosen due to the following reasons; similar area, same rectangular plan shape, they are both Coptic Orthodox church and follow the same Basilica plan typology. Moreover, similar passive design strategies were found in both such as openings (windows and doors) and the roof structure (domes, vaults and flat roof) along with the similar context which puts them in the same weather conditions.

\subsection{Case Study: St. Barbara Church}

St. Barbara church is an ancient church located at the eastern part of the Babylon fort, old Cairo, since the 5 th century and then was rebuilt in the $11^{\text {th }}$ century [31]. The church is rectangular and follows the Roman Basilica typology [32]. St. Barbara church roof is formed of different structures such as wooden barrel vault, dome and flat roof [5]. The passive strategies used in the church were the different materials, colors, shading devices and the different window sizes. Moreover, St. Barbara depended on natural ventilation through openings and with the assistance of the arches to enhance the air flow within the space. St. Barbara church used artificial lighting instead of natural light due to the windows size and shading device used. However, there was no air conditioning in the church. 


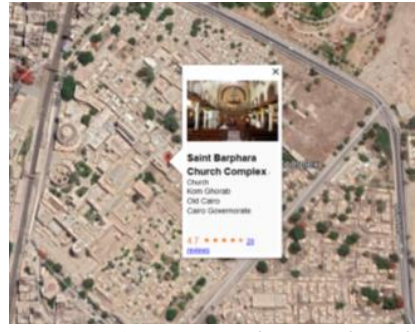

Figure 1: St. Barbara church location map. Source: Google maps

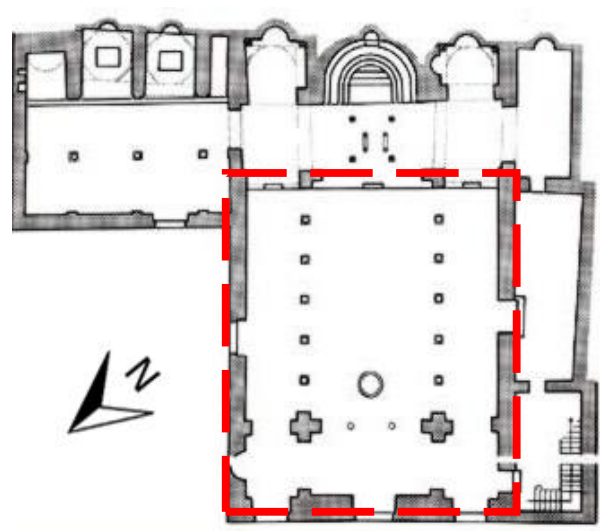

Figure 2: Plan view of St. Barbara. Source: Archnet.com

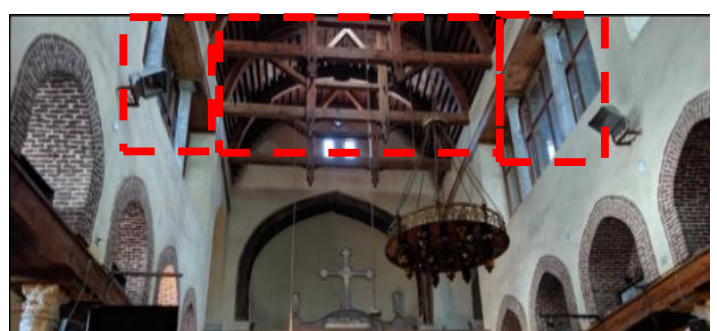

Figure 3: Roof structure, windows and arches of St. Barbara church. Source: [33])

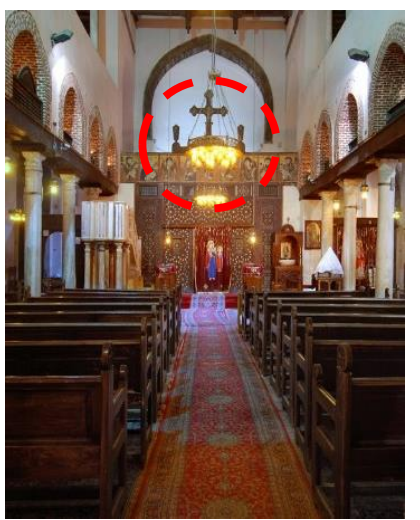

Figure 4: Artificial lights inside St. Barbara church. Source: Google images

\subsection{Case Study: Virgin Mary Church}

Virgin Mary church is located in Marashly, Zamalek. It was built in 1960 by the very wellknown architect Ramses Wissa Wassef [7]. The church is raised by flights of stairs as it is in the first floor due to the site restrictions and conditions of the area. The church plan is rectangular and follows the Basilican plan typology. The roof structure of the church is combined of ribbed vaulted roof and domes. The passive techniques used in the church were different materials, colors, structure system, various shading devices and the various window sizes. Virgin Mary church depended on natural ventilation through the openings and the occurrence of the roof structure enhancing the air flow within the space. Moreover, the large windows allow huge amount of light to penetrate into the space but the louvers placed on the windows prevented the light from penetrating giving rise to the need of having artificial light. However, with all these passive design strategies, the church needed to use air conditioning.

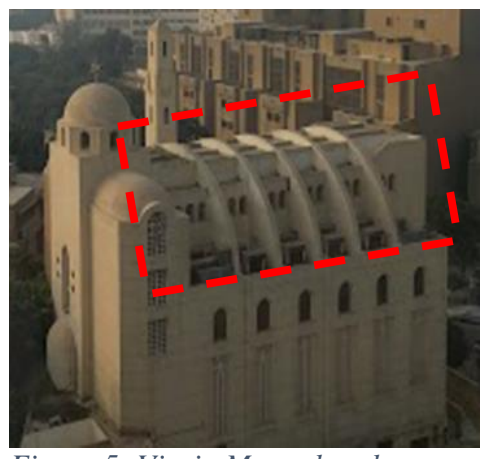

Figure 5: Virgin Mary church external view. Source: Google images

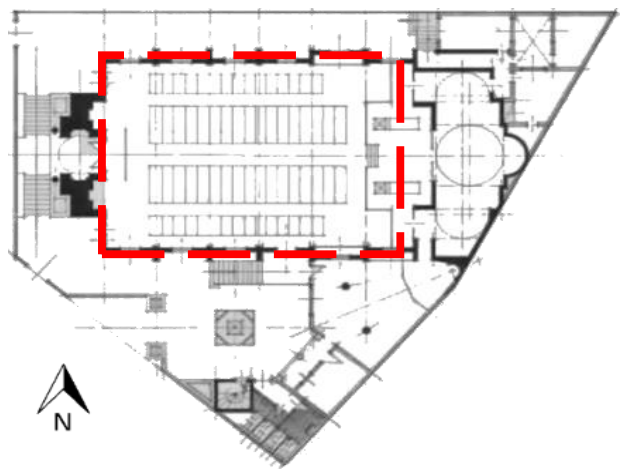

Figure 6: Plan of Virgin Mary church. Source: by Author

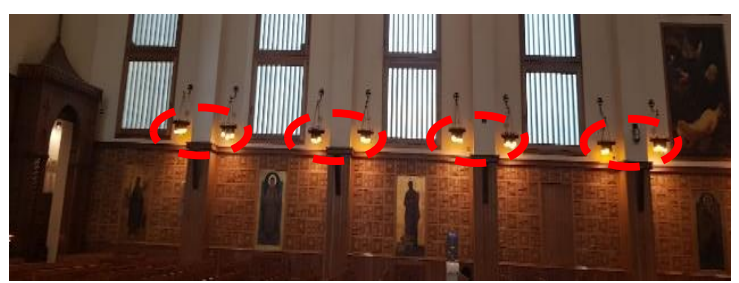

Figure 7: Natural light through windows but prevented by the louvers and enlightening using artificial lights. Source: by Author 


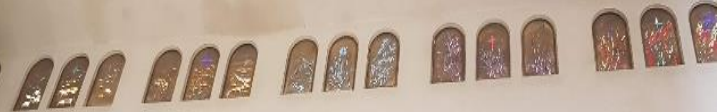

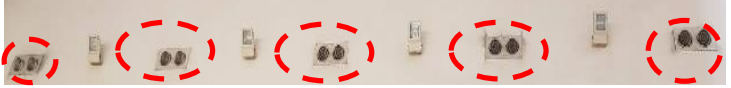

Figure 8: Air conditioning location within the space. Source: by Author

Table 1: Comparative analysis between the different church typology and the various passive techniques.

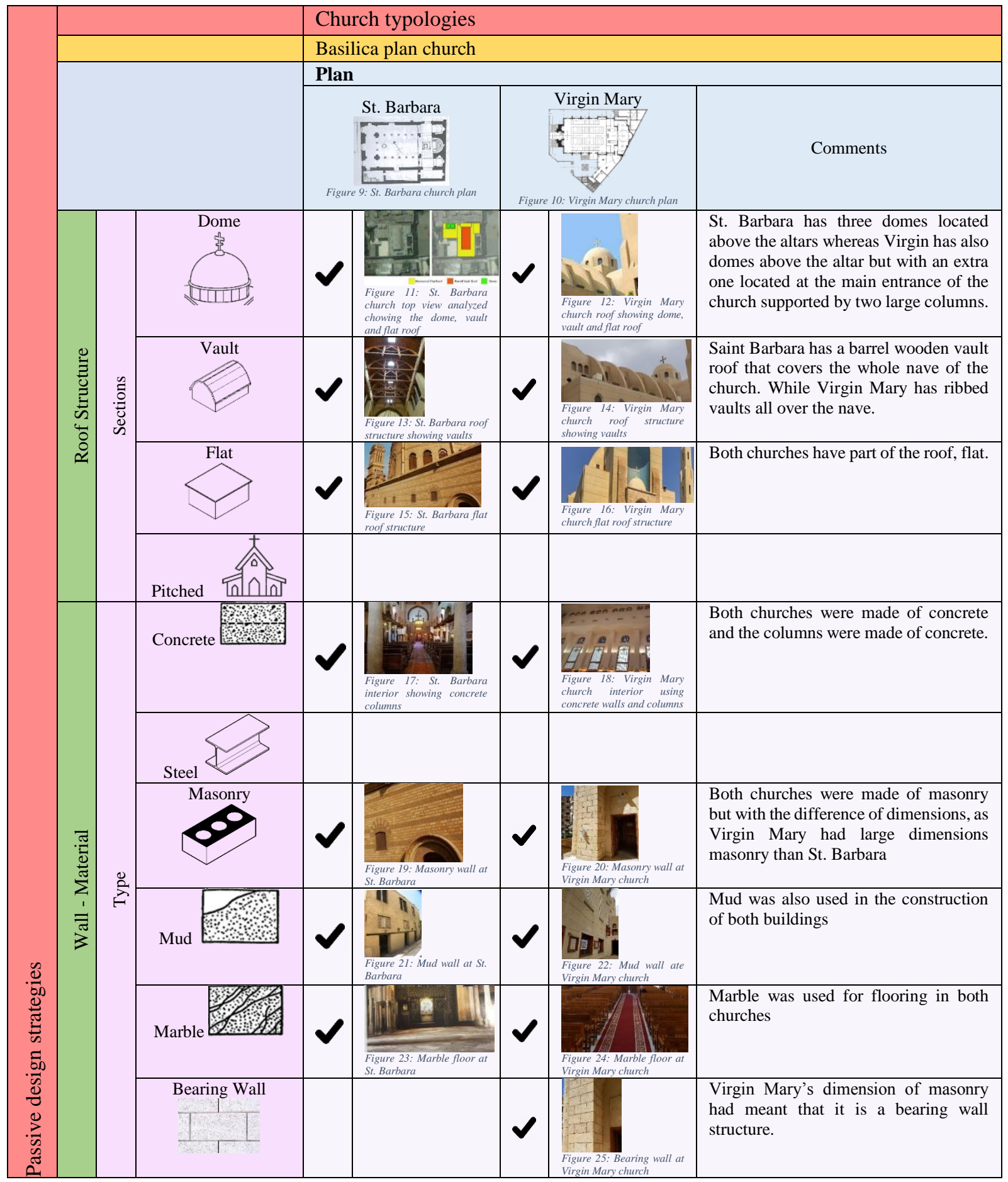




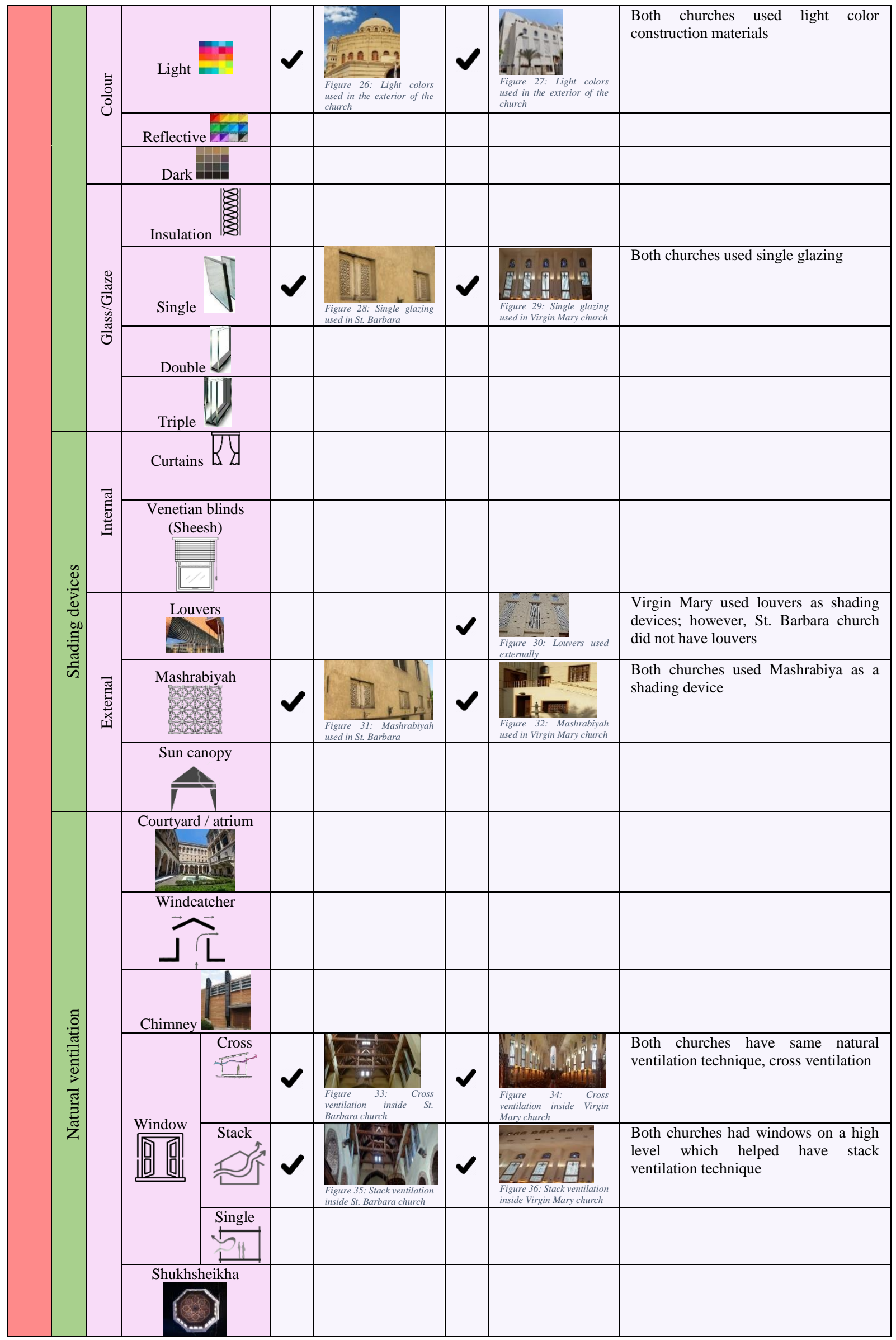




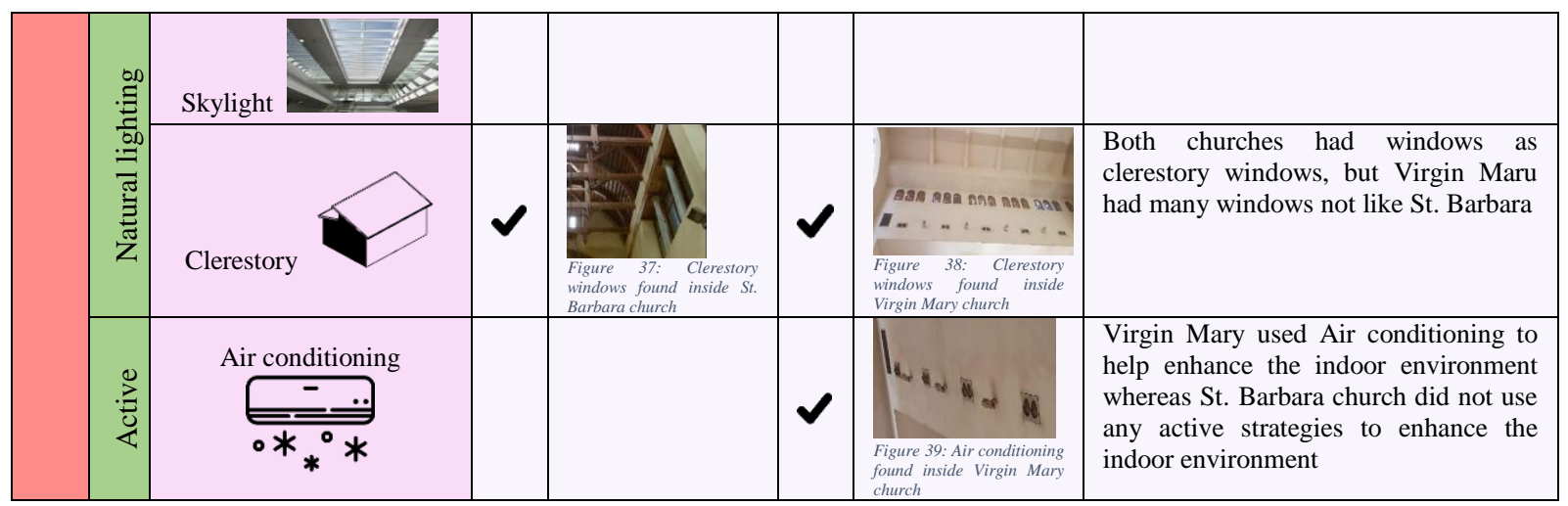

\section{Material and Method}

A simulation should be done to analyse thermal energy behaviours of the building to be able to reduce energy consumption and enhance indoor environmental quality (IEQ) [34]-[36]. According to Mukhtar et al. (2019), there are around 20 simulation programs which are; Design Performance Viewer (DPV), DesignBuilder, Ecotect, EnergyPlus, eQUEST, EcoDesigner, ESP-r, Green Building Studio, etc. However, DesignBuilder apart from the others offers a variety of environmental performance information like comfort conditions, the maximum summertime temperatures, HVAC components sizes, carbon emissions and energy consumption [37]. DesignBuilder is very similar to Ecotect but exceeds it by having EnergyPlus plugged in it, inserting all fabric and glazing information, as it uses the newest EnergyPlus mockup engine to compute building performance and is appropriate for use by architects, building services engineers, energy consultants, and university departments [37]. Some distinctive practices that DesignBuilder operate are thermal simulation of naturally ventilated buildings, calculation of the temperature, velocity and pressure distribution inside and around the building by using CFD, which are the main focus in this research and the reason of choosing design builder.

\section{Simulation Process}

Virgin Mary church was selected for thermal condition examination, as a base case model, because despite all these implemented passive strategies found, there was still a need in installing air conditioning to maintain the indoor thermal condition within the space. Moreover, glazing parameter was chosen to test the adjustments made in the base case model regarding the use of double, triple and insulation wall in the enhancement of thermal comfort that occurred. It was chosen because compared to the other passive techniques it is the simplest, fastest, most reasonable and most economical. The following is the thermal data results recorded of the base case model and the three different adjustments made.

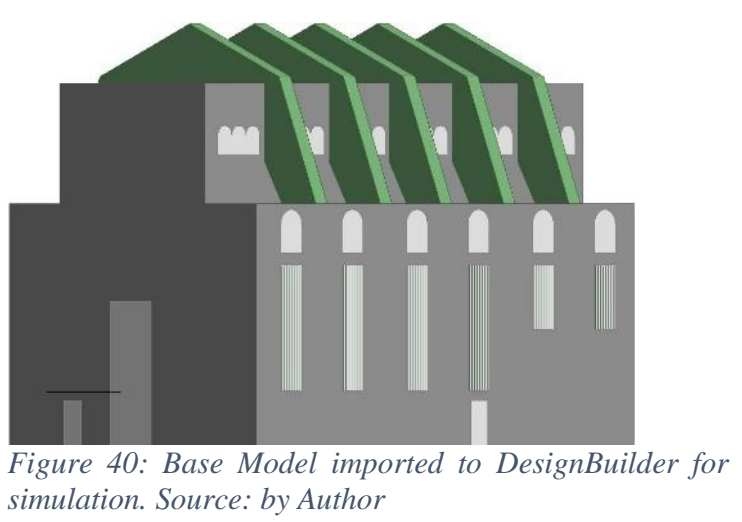

\subsection{Base Case Simulation Results}

The simulation results of the base case model show that the inside air temperature ranges between $27.16-33.72^{\circ} \mathrm{C}$ during a typical summer week. The solar transmitted through the exterior windows was between 0.00 and $10.41 \mathrm{~kW}$. The relative humidity within the space was $38.43-73.51 \%$. The total fresh air is equal to the addition of mechanical ventilation, natural ventilation and air infiltration, but in this simulation, there was no HVAC system i.e., no mechanical ventilation. So, the total fresh air represents the natural ventilation with air infiltration which ranged between 0.19 and $12.19 \mathrm{ac} / \mathrm{h}$. 


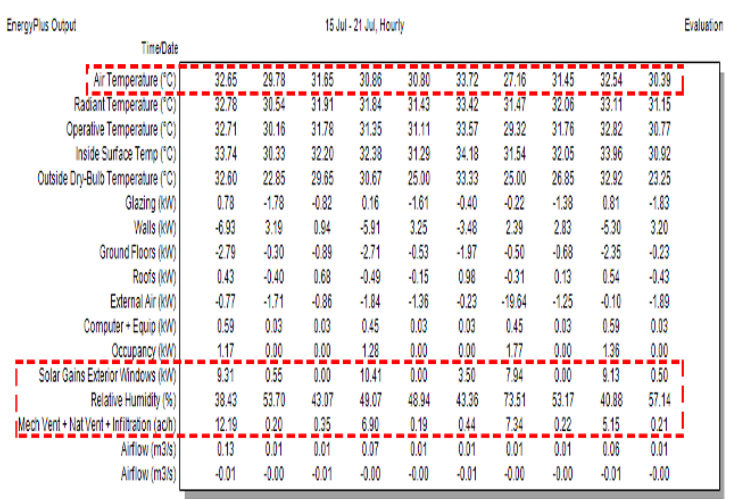

Figure 41: Base case model simulation results. Source: by Author

\subsection{Double-Glazing Simulation Results}

The following figure shows the settings being modified to change window glazing of the project to be double glazing. Simulation results of the double-glazing case shows the air temperature ranges between $27.09-33.70^{\circ} \mathrm{C}$ during a typical summer week. The solar gains through the exterior windows were between 0.00 and $9.71 \mathrm{~kW}$. The relative humidity within the space was $38.45-73.77 \%$. Total fresh air representing natural ventilation with air infiltration only shows a range of 0.18 and $12.19 \mathrm{ac} / \mathrm{h}$.

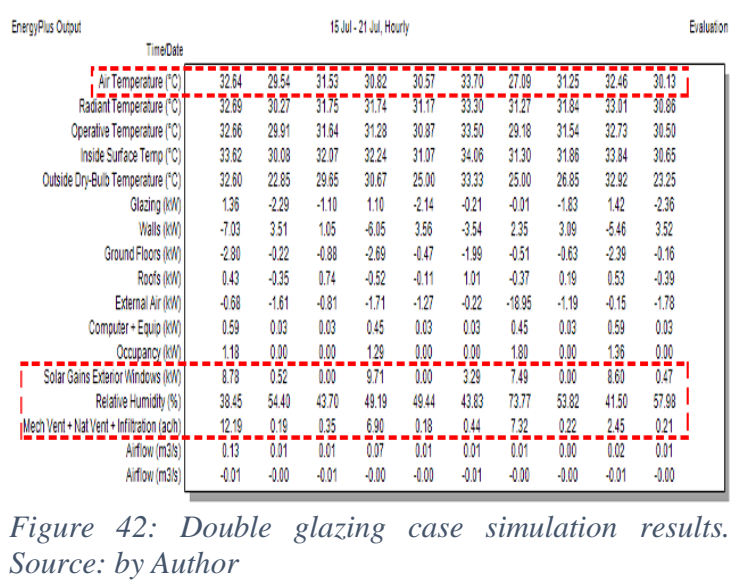

\subsection{Triple-Glazing Simulation Results}

The glazing template was edited to be triple glazing window as shown in Figure 43. Air temperature range inside the space is $27.08-$ $33.63^{\circ} \mathrm{C}$. Solar gains by the exterior windows ranges from 0.00 to $9.18 \mathrm{~kW}$. Relative Humidity range shown in Figure 43 to be 38.84 $-73.8 \%$. The total fresh air ranges between 0.19 and $12.13 \mathrm{ac} / \mathrm{h}$.

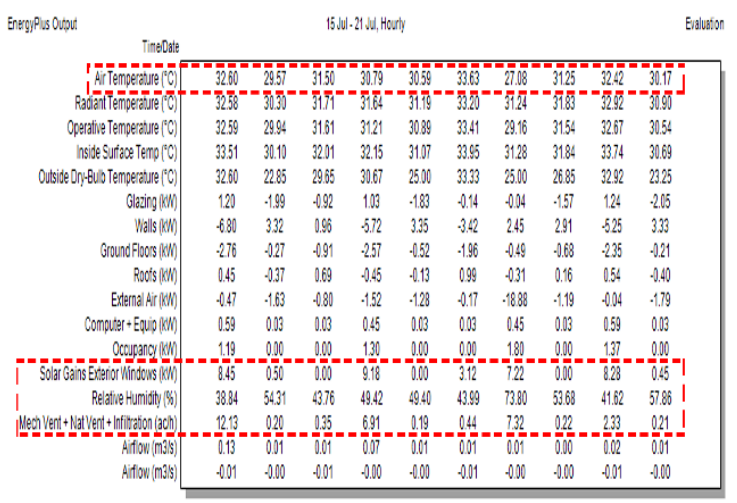

Figure 43: Triple glazing case simulation results. Source: by Author

\subsection{Wall Insulation Simulation Results}

After returning the glazing option back to its origin, exterior walls construction has been modified to contain insulation, Figure 44. Simulation results made by DesignBuilder program show that the air temperature ranges between 27.16 and $33.72^{\circ} \mathrm{C}$. Moreover, Solar gains through the exterior windows show a range of $0.00-10.41 \mathrm{~kW}$. Relative humidity has a wide range, 38.42 and $73.52 \%$. Natural ventilation and infiltration range are 0.19 and $12.19 \mathrm{ac} / \mathrm{h}$.

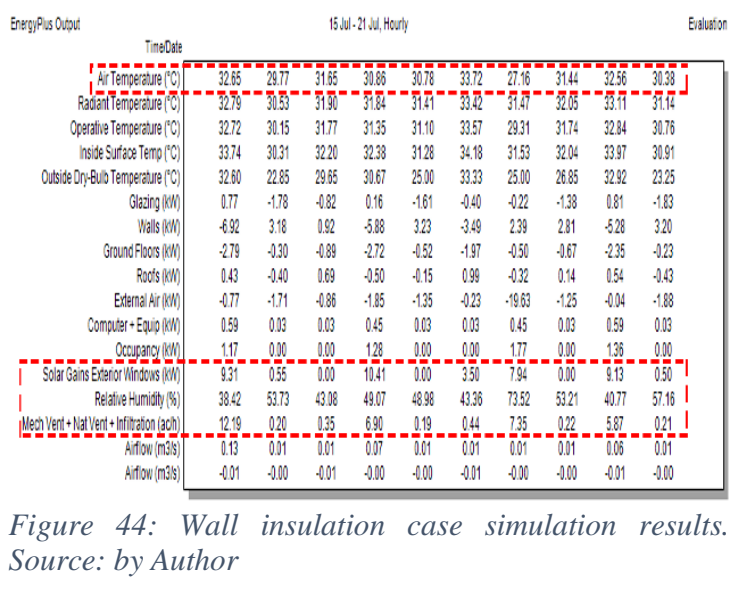

\section{Discussion}

A comparison of the simulation results was done between the base case model, double glazing case model, triple glazing case model and the wall insulation case model illustrating the average calculation of air temperature results, solar gains through exterior windows, relative humidity and total fresh air as the simulation was carried out for a typical summer week. 


\subsection{Air Temperature}

The following figure demonstrates the results of the average air temperature, within the typical summer week, for each case model. It is observed that triple glazing has caused the most decrease in the air temperature within the space, following it the double-glazing, which means that the air within the space became cooler increasing the chance of an enhancement in the thermal comfort conditions within the space. However, the insulation had a slight impact on the air temperature as it is very close to the base case model's air temperature. Therefore, it is recommended to implement triple glazing to attain indoor thermal comfort.

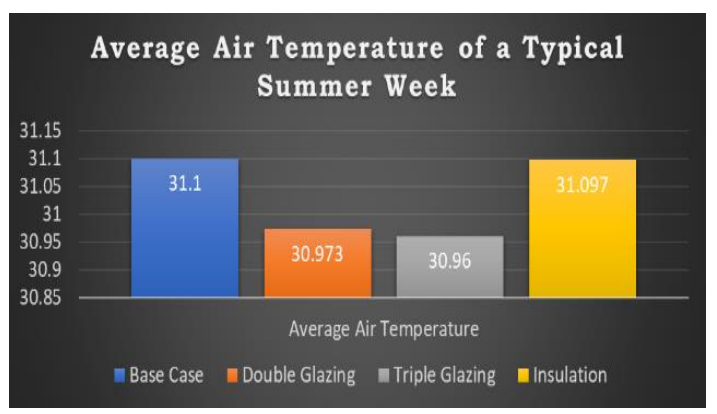

Figure 45: Average air temperature of typical summer week for the base case, double glazing, triple glazing and wall insulation. Source: by Author

\subsection{Solar Gains Through Exterior Windows}

The figure shows the average simulation results of a typical summer week solar gains through the exterior windows. Results illustrate that triple glazing had the most effect on decreasing the amount of heat being transmitted through the windows and again, after it comes the double glazing. This indicates that the chance of heat transmitting through the exterior walls has decreased which will maintain the indoor thermal comfort conditions within the space. Nevertheless, insulation did not have any impact on reducing the solar gain as its result is the same as the base case result. Therefore, it is better to use triple glazing in order to decrease the amount of heat penetrating into the indoor space.

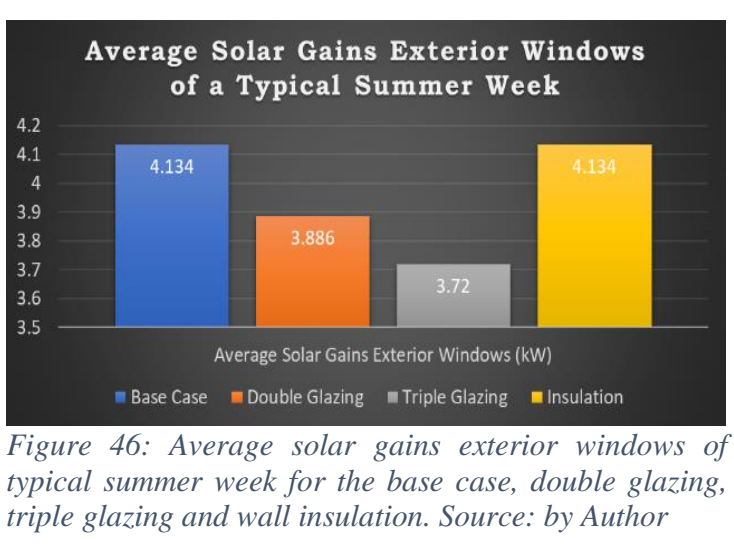

\subsection{Relative Humidity}

The comparison between the four models in relation to their average relative humidity results is shown in the Figure 16. The results show that, with the existence of triple glazing and double glazing, humidity level increases very much, which is a disadvantage as the aim is to provide users with thermal comfort within the space which means decreasing humidity level. Moreover, the usage of insulation does not make it better as it also higher humidity level. So, keeping the base case model as it is, looks as the best option aiming to decrease humidity.

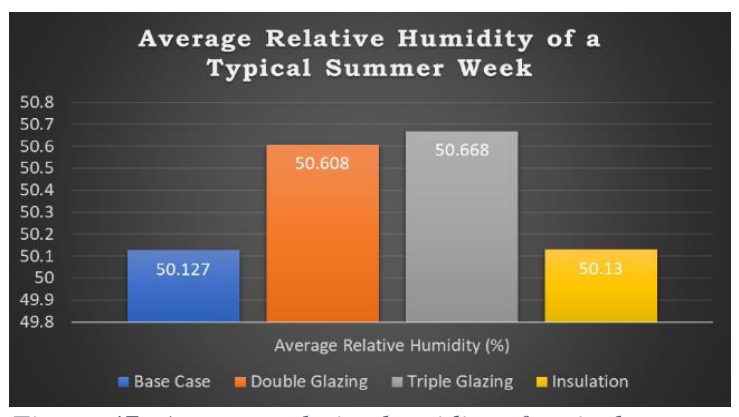

Figure 47: Average relative humidity of typical summer week for the base case, double glazing, triple glazing and wall insulation. Source: by Author

\subsection{Total Fresh Air}

Results shown in Figure 17 illustrate, the average of the total fresh air throughout a typical summer week. It is noticed that insulation allows more fresh air to be in the space compared to the base model case and the two glazing cases. Having more fresh air entering the space is an advantage as fresh air helps in enhancing the indoor thermal comfort allowing the user to feel comfortable. As triple glazing and double glazing cause a drop in the amount of fresh air flowing into the space. Therefore, it is recommended to insert 
insulation in walls to allow more fresh air to enter indoor spaces.

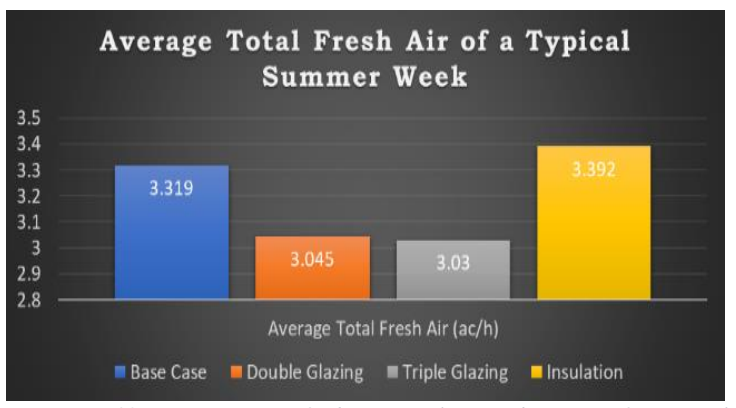

Figure 48: Average of the Total Fresh Air of typical summer week for the base case, double glazing, triple glazing and wall insulation. Source: by Author

\subsection{Simulation Results}

Results showed that changes implemented had a positive effect on the base case. The triple glazing was the most effective as it has decreased the air temperature, making it cooler for the users, hence, providing an enhancement in the indoor space thermal conditions, compared to double glazing, insulation and the base case. It has also proofed to have a strong impact on preventing solar gains from windows, thus protecting the indoor space from heat entering inside the space. However, when it came to the relative humidity, triple glazing had a negative impact, meaning, increasing the relative humidity within the space but the insulation in the wall helped maintain the humidity inside the nave and had a positive impact in allowing more total fresh air to flow inside the space.

To conclude, in order to decrease air temperature and solar heat gains through exterior windows, it is recommended to use triple or double glazing, depends on the price. But, if aiming on maintaining humidity level or increasing total air flow inside the space, therefore, insulation in walls will be a suitable recommendation.

\section{Conclusion}

Main contribution of this paper is the analysis of the passive design techniques that are included in the Coptic Orthodox churches building from the $11^{\text {th }}$ century to the $20^{\text {th }}$ century. Verification was guaranteed after the examination of the passive techniques applied (triple glazing, double glazing and insulation) using DesignBuilder and the thermal comfort enhancement achieved inside the church building. Therefore, it is of usefulness for application in the Coptic Orthodox churches building in order to enhance indoor thermal comfort.

\subsection{Passive design to be applied}

The set of guidelines represent the passive design strategies that can be implemented in modern Coptic Orthodox churches in Egypt to enhance their thermal comfort which are deduced as ticked in the literature review outcome matrix based on what was found applied in real life.

\section{Roof Structure}

Domes are basics but Vaults can be used as well as it has been observed applied in several churches. Flat roofs are used normally but they don't really enhance thermal comfort. However, pitched roof is usually not used in Egypt as it was made for rainy climate region. Therefore, they are minor in Egypt and in churches.

\section{Wall - Material - Glazing}

All materials can be used but not all materials improve thermal comfort, some of them absorb heat causing hot surfaces resulting in thermal discomfort. Light and reflective colours are preferable yet dark is rejected. All glazings are suitable in churches. In addition, insulation can also be used in churches to preserve the indoor temperature.

\section{Shading Devices}

The most suitable outdoor shading devices are louvers and mashrabiya.

\section{Natural Ventilation Strategies}

Windows are the widely and most appropriate used element to provide natural ventilation within the closed area of the church, allowing cross ventilation.

\subsection{Recommendation}

It is recommended to follow the following steps to achieve results of simulating several passive strategies and acknowledging which one is the most effective

1- Identify key passive strategies that could be adjusted according to which is easiest, low cost and fast change

2- Experiment each strategy as follows a- Build the base model mimicking its original state 
b- Start adjusting each factor

c- Run the simulation for the base case and the various adjustments made
4- Compare the results of the changes to the base case and to each other to know which change had the most impact

3- Record the results

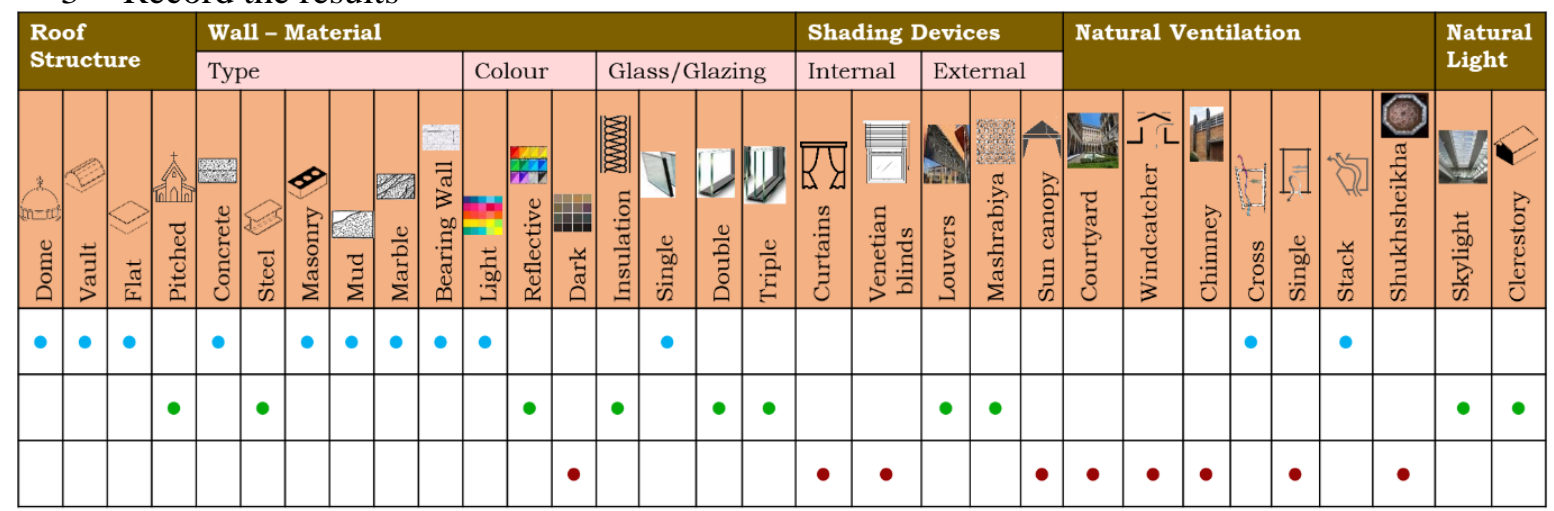

Figure 49: Light blue: basically, used in churches; Green: can be used in Coptic Orthodox Churches; Dark red: not used in Coptic Orthodox

\section{Acknowledgement}

Throughout the writing of this research, I have received a great deal of support, assistance and encouragement.

Above all, I would first like to thank God for the great arrangements and blessings felt throughout the journey of this dissertation.

I would like to express my gratitude to my supervisor, Professor Gehan Nagy, whose expertise was invaluable in formulating the research questions, methodology and the whole structure.

I would also like to thank my tutor, Arch. Dalya Maguid, for her valuable guidance throughout my studies.

\section{References}

[1] M. J. Holmes and J. N. Hacker, "Climate change, thermal comfort and energy: Meeting the design challenges of the 21st century," Energy Build., vol. 39, no. 7, pp. 802-814, 2007, doi: 10.1016/j.enbuild.2007.02.009. E.

Keller, "finalcopyofpresentationonglobalwarming," Introd. to Environ. Geol., 1999.

[3] M. N. Guirguis, K. M. Dewidar, S. M. Kamel, and M. F. Iscandar, "A Semiotic Investigation of the Architecture of The Coptic Church," 2016, no. August, pp. 1-15.

[4] S. R. Morgan, "Shaker's Typological Classification of Coptic Orthodox Church design An application on Historic Coptic churches of Old Cairo and Fustat," Eng. Res., vol. 151, no. September, pp. 41-44, 2016.
[5] S. R. Morgan, "The various typologies of Historic Coptic Orthodox Church design," Eng. Res., vol. 151, no. September, pp. 57-62, 2016.

[6] M. Nabil Guirguis, K. M. Dewidar, S. M. Kamel, and M. F. Iscandar, "Categorization of symbolism in religious architecture; a case study of the Coptic Orthodox church architecture," Alexandria Eng. J., vol. 59, no. 1, pp. 533-545, 2020, doi: 10.1016/j.aej.2020.01.031.

[7] M. Nabil and K. Dewidar, Coptic Orthodox Art and Architecture; Development and Design of Church Understanding Development and Interpretations of Church Design, no. December. 2016.

[8] N. S. Ramzy, "The impact of local environment aspects on Coptic architecture in Egypt," Alexandria Eng. J., vol. 51, no. 4, pp. 325-341, 2012, doi: 10.1016/j.aej.2012.07.009.

[9] T. Blázquez, S. Ferrari, R. Suárez, and J. J. Sendra, "Adaptive Approach-Based Assessment of a Heritage Residential Complex in Southern Spain for Improving Comfort and Energy Efficiency Through Passive Strategies: A Study Based on a Monitored Flat," Energy, vol. 181, pp. 504-520, 2019, doi: 10.1016/j.energy.2019.05.160.

[10] M. Khoshbakht, Z. Gou, and F. Zhang, "A Pilot Study of Thermal Comfort in Subtropical Mixed-Mode Higher Education Office Buildings with Different Change-Over Control Strategies," Energy Build., vol. 196, pp. 194-205, 2019, doi: 10.1016/j.enbuild.2019.05.030.

[11] V. Vitale and G. Salerno, "A Numerical Prediction of the Passive Cooling Effects on Thermal Comfort for a Historical Building in Rome," Energy Build., vol. 157, pp. 1-10, 2017, doi: 10.1016/j.enbuild.2017.06.049.

[12] M. Fiorentini, G. Serale, G. Kokogiannakis, A. Capozzoli, and P. Cooper, "Development and 
evaluation of a comfort-oriented control strategy for thermal management of mixed-mode ventilated buildings," Energy Build., vol. 202, pp. 1-16, 2019, doi: 10.1016/j.enbuild.2019.109347.

[13] J. Fernandes, R. Mateus, H. Gervásio, S. M. Silva, and L. Bragança, "Passive strategies used in Southern Portugal vernacular rammed earth buildings and their influence in thermal performance," Renew. Energy, vol. 142, pp. 345-363, 2019, doi: 10.1016/j.renene.2019.04.098.

[14] S. Subhashini and K. Thirumaran, "A Passive Design Solution to Enhance Thermal Comfort in an Educational Building in the Warm Humid Climatic Zone of Madurai," J. Build. Eng., vol. 18, no. December 2017, pp. 395-407, 2018, doi: 10.1016/j.jobe.2018.04.014.

[15] I. Rajendran and D. P. S. Chani, "Passive Strategies for Indoor Thermal Comfort in Warm Humid Climate," no. Fig 2, pp. 1-10, 2013.

[16] A. S. of H. R. and A. conditioning E. ASHRAE, "Thermal Environmental Conditions for Human Occupancy," ASHRAE Stand., vol. 2004, p. 3, 2004, [Online]. Available: http://www.aicarr.org/Documents/Editoria_Libr i/ASHRAE_PDF/STD55-2004.pdf.

[17] I. Atmaca, O. Kaynakli, and A. Yigit, "Effects of Radiant Temperature on Thermal Comfort," Build. Environ., vol. 42, no. 9, pp. 3210-3220, 2007, doi: 10.1016/j.buildenv.2006.08.009.

[18] M. Castilla, J. D. Álvareza, M. Berenguela, F. Rodrígueza, J. L. Guzmána, and M. Pérez, “A comparison of Thermal Comfort Predictive Control Strategies," Energy Build., vol. 43, no. 10, pp. 2737-2746, 2011, doi: 10.1016/j.enbuild.2011.06.030.

[19] P. Fanger, "Calculation of Thermal Comfort: Introduction of a Basic Comfort Equation," ASHRAE Trans., vol. 73(2), no. III4, pp. 1-2, 1967.

[20] M. S. Alwetaishi, "Impact of building function on thermal comfort: A review paper," Am. J. Eng. Appl. Sci., vol. 9, no. 4, pp. 928-945, 2016, doi: 10.3844/ajeassp.2016.928.945.

[21] A. B. Daemei, S. R. Eghbali, and E. M. Khotbehsara, "Bioclimatic Design Strategies: A Guideline to Enhance Human Thermal Comfort in Cfa Climate Zones," J. Build. Eng., vol. 25, no. April, p. 100758, 2019, doi: 10.1016/j.jobe.2019.100758.

[22] K. C. Parsons, "The Effects of Gender, Acclimation State, The Opportunity to Adjust Clothing and Physical Disability on Requirements for Thermal Comfort," Energy Build., vol. 34, no. 6, pp. 593-599, 2002, doi: 10.1016/S0378-7788(02)00009-9.

[23] C. Butters, "Enhancing Air Movement By Passive Means in Hot Climate Buildings," Elit. Res. Program, Energy Low Income, vol. 2, no.
May 2015, pp. 1-9, 2015.

[24] M. El Gamal, "Resource Efficient Architecture and Planning for Egypt," HafenCity University, 2014.

[25] S. Sahid, I. Surjamanto, and I. S. Triyadi, "Role of Passive and Active Strategy in Green Building Context," 2004, [Online]. Available: Green building, passive system, active system.

[26] H. Fathy, "Natural energy and vernacular architecture: principles and examples with reference to hot arid climates," Chicago Univ. Chicago Press, 1986.

[27] H. Farouh and L. Amer, "Passive and Hybrid Techniques for Low Cost Energy Effecient Housing in Hot Dry Climate," J. Al-Azhar Univ. Eng. Sect., vol. 11, no. 41, pp. 1265-1274, 2016, doi: 10.21608/auej.2016.19314.

[28] B. Givoni, "Comfort, Climate analysis and building design giudelines," B. Givoni, Energy Build., no. New York, pp. 11-23, 1992.

[29] J. Nazarova and A. Borodinecs, "Evaluation Of Temperature And Humidity Regime In An Orthodox Church," Constr. Sci., vol. 15, no. 1, pp. 19-23, 2014, doi: 10.2478/cons-2014-0003.

[30] A. J. Butler, "The Ancient Coptic Churches of Egypt," Clarendon Press, vol. 1, pp. 1-412, 1884.

[31] M. Kamel, "No Title," Copts-united, 2019. https://www.copts-

united.com/Article.php?I=3943\&A=524472 (accessed Apr. 09, 2020).

[32] Trustpilot, "Church of St. Barbara," ASK ALADDIN - Your Egypt Travel Experts, 2019. https://www.ask-aladdin.com/egyptsites/coptic-monuments/barbara/.

[33] D. A. M. Rezk., Atlas of Islamic and Coptic Architecture in Cairo. 2003.

[34] A. T. Nguyen, S. Reiter, and P. Rigo, "A review on simulation-based optimization methods applied to building performance analysis," Appl. Energy, vol. 113, pp. 1043-1058, 2014.

[35] A. Mukhtar, M. Z. Yusoff, and K. C. Ng, "The potential influence of building optimization and passive design strategies on natural ventilation systems in underground buildings: The state of the art," Tunn. Undergr. Sp. Technol., vol. 92, no. July, 2019, doi: 10.1016/j.tust.2019.103065.

[36] Y. N. Bahar, C. Pere, J. Landrieu, and C. Nicolle, "A thermal simulation tool for building and its interoperability through the Building Information Modeling (BIM) platform," Buildings, vol. 3, no. 2, pp. 380-398, 2013, doi: 10.3390/buildings 3020380 .

[37] A. R. Kibaya, "Thermal Comfort Analysis of a Naturally Ventilated Building. Case Study: College of Engineering, Design, Art and Technology (CEDAT) Building, Makerere University, Kampala-Uganda," Gavle, 2013.

\section{Creative Commons Attribution License 4.0} (Attribution 4.0 International, CC BY 4.0)

This article is published under the terms of the Creative Commons Attribution License 4.0

https://creativecommons.org/licenses/by/4.0/deed.en_US 